\title{
PEMANFAATAN DIGITAL MARKETING DALAM PEMASARAN PRODUK PARA PELAKU UMKM DI DESA PAGUYUBAN KECAMATAN WAY LIMA KABUPATEN PESAWARAN
}

\author{
Yuliana Saleh, Dian Rahmalia, Shinta Tantriadisti, I. Rani Mellya Sari \\ Jurusan Agribisnis Fakultas Pertanian Universitas Lampung, Bandar Lampung \\ Jl. Prof. Dr. Sumantri Brodjonegoro No.1 Bandar Lampung 35145 \\ Penulis Korespodensi : yuliana.saleh@fp.unila.ac.id
}

\begin{abstract}
Abstrak
Desa Paguyuban memiliki banyak potensi dan produk yang dihasilkan masyarakatnya. Pelaku UMKM di Desa Paguyuban melakukan pemasaran produknya secara konvensional dan belum melakukan pemasaran produk melalui digital marketing. Kegiatan pengabdian kepada masyarakat ini bertujuan untuk : 1) memberikan wawasan tentang konsep digital marketing dan produk-produk teknologi yang digunakan untuk pemasaran produk, 2) memberikan pelatihan dan simulasi tentang penggunaan media digital dalam pemasaran produk, 3) menyusun pesan persuasif efektif, dan 4) memberikan solusi untuk mewujudkan pelaku UMKM untuk mempromosikan produk melalui media digital. Kegiatan pengabdian dilakukan dengan menggunakan metode FGD, pelatihan dan pendampingan. Secara umum, kegiatan pengabdian kepada masyarakat berjalan dengan baik dan dapat meningkatkan pengetahuan masyarakat dari nilai ratarata 7 menjadi 9 atau meningkat 23,26\%. Kegiatan pelatihan dan pendampingan ini sangat baik dan tepat sasaran. Dari kegiatan ini, masyarakat mulai 1) memahami konsep digital marketing dan produk-produk teknologi yang dapat digunakan untuk pemasaran produk UMKM, 2) melatih dan mensimulasikan pemasaran produk UMKM dengan menggunakan media digital seperti facebook marketplace, instagram, dan shopee, 3) menyusun pesan persuasif efektif dan menarik, sehingga calon pembeli semakin tertarik untuk membeli produk UMKM nya, dan 4) membuat akun media sosial yang dikelola oleh para pelaku UMKM yang digunakan untuk mensosialiasikan dan mempromosikan produk UMKM nya.
\end{abstract}

Kata kunci : Digital marketing, pemasaran, UMKM

\section{Pendahuluan}

Desa Paguyuban memiliki banyak potensi desa dan produk yang dihasilkan oleh masyarakatnya. Para pelaku (Usaha Mikro Kecil dan Menengah) UMKM di Desa Paguyuban masih melakukan pemasaran produk secara konvensional. Para pelaku UMKM seharusnya dapat memanfaatkan media promosi konvensional dan berkolaborasi dengan pemasaran melalui media digital, sehingga para pelaku UMKM lebih maksimal dalam memasarkan produk. Hingga tahun 2021 ini, belum ada data yang menunjukkan para pelaku UMKM di Desa Paguyuban melakukan pemasaran produk melalui digital marketing. Hal ini perlu menjadi perhatian kita di tengah kemajuan teknologi dan informasi yang sedang berkembang saat ini.
Strategi digital marketing atau pemasaran online saat ini sangat penting dilakukan di masa pandemi Covid 19 dan dapat diyakini lebih efektif serta efesien untuk menjangkau target pasar yang diinginkan. Para pelaku UMKM dapat memanfaatkan digital marketing untuk memperoleh peluang yang besar, sehingga dapat mengekspansi penjualan produk mereka melalui media digital. Para pelaku UMKM perlu memanfaatkan bermacam cara untuk melakukan promosi dan meningkatkan penjualan produk, salah satunya dengan memanfaatkan peluang dan teknologi informasi yang ada.

Media promosi digital menjadi pilihan yang efektif untuk pelaku UMKM dalam mengembangkan bisnis dan menjangkau pasar nasional maupun internasional. Dengan menggunakan digital marketing, pelaku UMKM 
dapat menjangkau calon costumer yang lebih luas dan lebih banyak, tidak hanya terbatas pada suatu wilayah promosi saja. Digital marketing dapat menjangkau wilayah yang lebih luas dibanding pemasaran secara konvensional, sehingga hal ini menjadi pilihan yang solutif untuk ekspansi usaha para pelaku UMKM.

Menurut Hendriadi, Sari dan Padilah (2019), digital marketing merupakan salah satu usaha untuk memasarkan atau mempromosikan sebuah produk melalui media internet, agar dapat menjangkau konsumen maupun calon konsumen dengan cepat. Media internet yang sekarang ini populer digunakan untuk pemasaran produk antara lain Facebook, Instagram, Shopee dan media lainnya. Manfaat yang didapatkan dengan digital marketing selain dapat menjangkau pasar yang lebih luas dan mengefektifkan biaya pemasaran, juga membuat ruang dan waktu pemasaran yang tidak terbatas. Selain itu, digital marketing bersifat real time, sehingga pengusaha dapat langsung memperhatikan minat dan feed back dari pasar yang dituju, serta dapat memutuskan strategi penyesuaian terkait konten iklan untuk hasil yang lebih baik dengan lebih cepat.

Media sosial secara sederhana diartikan sebagai salah satu platform media online untuk mendukung komunikasi secara interaktif. Media sosial banyak dimanfaatkan oleh masyarakat untuk pemasaran yang berbasis digital. Pemasaran berbasis digital (digital marketing) adalah terobosan terbaru dalam melakukan pemasaran produk secara online (Purwana, Rahmi, dan Aditya, 2017).

Penelitian Pradiani (2018) pun sudah membuktikan bahwa pemasaran secara online memang dapat meningkatkan hasil penjualan produk, karena sekarang ini masyarakat cenderung lebih suka mencari referensi secara online bahkan membeli produk secara online. Pemasaran secara online juga dapat meningkatkan jangkauan pemasaran yang tidak dapat atau susah dijangkau oleh pemasaran offline (Febriyantoro dan Arisandi, 2018).

Namun, para pelaku UMKM di Desa Paguyuban kurang memiliki wawasan terkait konsep digital marketing, dimana lingkup digital marketing tidak hanya pada kajian promosi dan pemasaran saja, tetapi juga mencakup pada penggunaan dan optimalisasi media internet dalam proses komunikasi dan penjualan produk. Selain itu, para pelaku UMKM juga belum mengetahui produk teknologi informasi yang dapat digunakan untuk pemasaran produknya. Padahal, saat ini banyak produk teknologi yang dapat digunakan dalam pemasaran produk, dimana tidak hanya terbatas pada pemanfaatan media sosial saja.

Oleh karena itu, dalam rangka dalam membantu para pelaku UMKM dalam melakukan pemasaran produknya, yang pada akhirnya dapat meningkatkan pendapatan dan kesejahteraan masyarakat, maka tim melakukan kegiatan Pengabdian Kepada Masyarakat dengan judul "Pemanfaatan Digital Marketing Dalam Pemasaran Produk Para Pelaku UMKM di Desa Paguyuban Kecamatan Way Lima Kabupaten Pesawaran."

Tujuan kegiatan Pengabdian Kepada Masyarakat (PKM) ini adalah:

a. Memberikan tambahan wawasan kepada para pelaku UMKM di Desa Paguyuban tentang konsep digital marketing dan produk-produk teknologi yang dapat digunakan untuk pemasaran produk.

b. Melatih dan mensimulasikan penggunaan media digital dalam pemasaran produk.

c. Menyusun pesan persuasif efektif, sehingga calon pembeli semakin tertarik untuk membeli produk UMKM.

d. Memberikan solusi untuk mewujudkan keinginan para pelaku UMKM untuk mempromosikan produk mereka melalui media digital.

\section{Metode Pelaksanaan}

Metode yang digunakan adalah a) Focus Group Discussion (FGD) dilakukan kepada aparat pemerintah Desa Paguyuban Kecamatan Way Lima Kabupaten Pesawaran dan beberapa pelaku UMKM untuk diketahui permasalahan yang dihadapi oleh para pelaku UMKM terkait pemasaran produknya, b) Pelatihan dengan metode ceramah, metode tanya jawab dan metode simulasi, c)) Pendampingan dengan metode anjang sana. Pada kegiatan anjang sana ini akan dilakukan kunjungan ke beberapa para pelaku UMKM di Desa Paguyuban Kecamatan Way Lima Kabupaten Pesawaran.

Tahapan pelaksanaan Pengabdian Kepada Masyarakat (PKM) ini yaitu:

a. Tahap persiapan

1) Tim Pengabdian Kepada Masyarakat memilih Desa Paguyuban Kecamatan Way 
Lima Kabupaten Pesawaran, karena Desa Paguyuban memiliki banyak potensi desa yang dikelola oleh masyarakat yang produktif dan menghasilkan produk-produk yang dapat dijual pada masyarakat. Hal ini dapat diketahui oleh tim, karena tim pernah melaksanakan pengabdian kepada masyarakat terkait pemetaan wilayah berbasis potensi Desa Paguyuban, sehingga telah diketahui potensi-potensi desa yang dimiliki. Pengabdian Kepada Masyarakat ini merupakan tindak lanjut dari pengembangan potensi yang dibutuhkan oleh para pelaku UMKM di Desa Paguyuban. Sebelum pelaksanaan, tim Pengabdian Kepada Masyarakat mematangkan materi pelatihan digital marketing yang nantinya dibutuhkan oleh para pelaku UMKM di Desa Paguyuban.

2) Tahapan survei dan permohonan izin pelaksanaan Pengabdian Kepada Masyarakat ke Pemerintah Desa Paguyuban serta penentuan lokasi kegiatan dan sasaran.

3) Tahapan sosialisasi atau undangan pelatihan berisi tentang konsep digital marketing dan produk-produk teknologi yang dapat digunakan sebagai penunjang kegiatan pemasaran kepada para pelaku UMKM di Desa Paguyuban.

b. Tahap pelaksanaan

1) Para pelaku UMKM di Desa Paguyuban diminta untuk mengisi daftar hadir dan mengambil bahan pelatihan (hardcopy) yang sudah disediakan tim.

2) Para pelaku UMKM di Desa Paguyuban untuk mengisi lembar Pre-test, sebelum pelaksanaan pelatihan dimulai.

3) Tim Pengabdian Kepada Masyarakat memberikan pelatihan dengan ceramah dan diskusi terkait pentingnya melakukan penjualan dengan menyesuaikan perkembangan yang sedang terjadi pada saat ini. Tren penjualan produk yang sedang marak di masyarakat adalah penjualan dengan menggunakan media digital (Guna, dkk., 2013). Materi pelatihan berisi tentang konsep digital marketing dan produk-produk teknologi yang dapat digunakan sebagai penunjang kegiatan pemasaran. Tim pengabdian juga memberikan cara-cara melakukan pemasaran produk dengan memanfaatkan media sosial yang sudah tersedia dan banyak digunakan oleh masyarakat Indonesia seperti Facebook, Instagram, Shopee, dan lain-lain. Hal ini dilakukan, agar produk yang dihasilkan oleh para pelaku UMKM di Desa Paguyuban dapat diketahui oleh seluruh elemen masyarakat, sehingga penjualan dan pendapatan akan semakin meningkat.

4) Para pelaku UMKM di Desa Paguyuban untuk mengisi soal post-test, setelah pelaksanaan pelatihan diberikan.

5) Pendampingan juga dilakukan ke beberapa para pelaku UMKM.

\section{Hasil dan Pembahasan}

Tim dosen pengabdian kepada masyarakat mengunjungi Desa Paguyuban untuk mengurus perizinan pelaksanaan kepada pengabdian kepada masyarakat tentang Pemanfaatan Digital Marketing Dalam Pemasaran Produk Para Pelaku UMKM di Desa Paguyuban Kecamatan Way Lima Kabupaten Pesawaran pada hari minggu tanggal 20 Juni 2021 (Gambar 1).

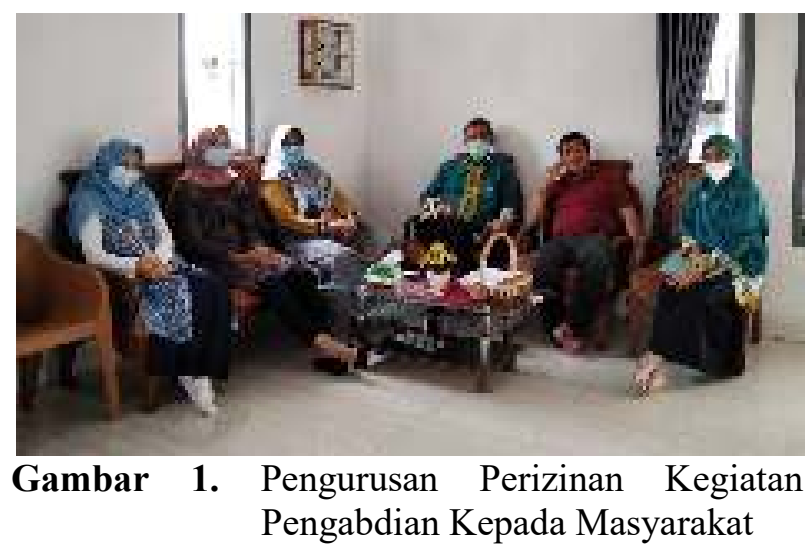

Tim disambut oleh Kepala Desa Paguyuban Bapak Imam Khudrli. Tim dosen diberikan izin untuk melakukan kegiatan pengabdian kepada masyarakat dan diminta untuk berkoordinasi dengan aparat Desa Paguyuban terkait hal-hal yang perlu dipersiapkan. Beliau menyatakan bahwa masyarakat Desa Paguyuban siap untuk mengikuti seluruh rangkaian kegiatan pengabdian kepada masyarakat dari Universitas Lampung.

Selanjutnya, tim dosen melakukan kunjungan ke Balai Desa Paguyuban untuk berdiskusi atau melakukan Focus Group Discussion dengan aparat Desa Paguyuban pada hari Rabu tanggal 14 Juli 2021 (Gambar 2). 

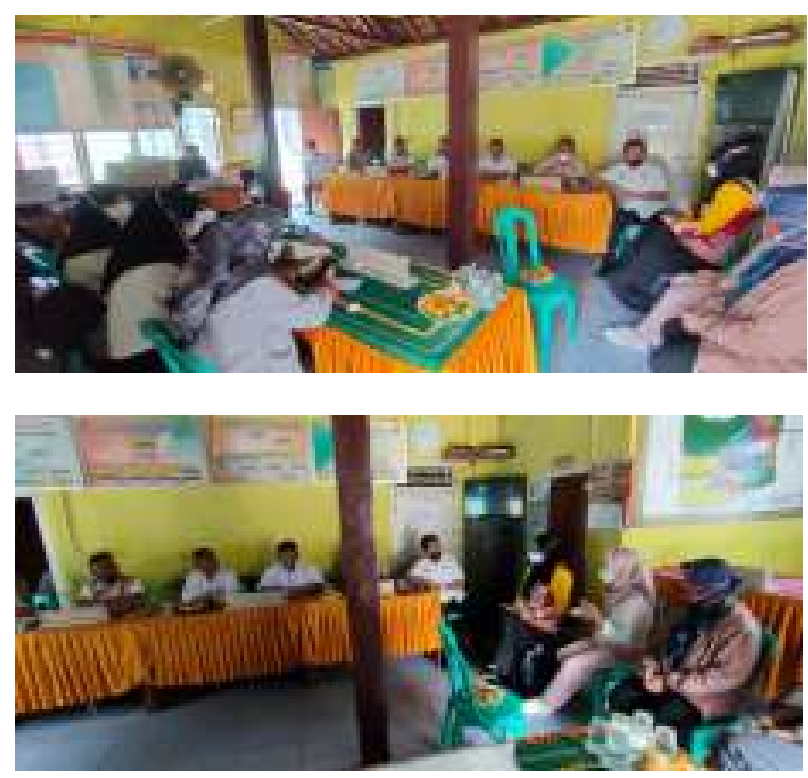

Gambar 2. FGD Tim PKM dengan Aparat Desa Paguyuban

Kegiatan FGD dibuka oleh ketua tim PKM Ibu Yuliana Saleh, S.P., M.Si. FGD ini dilakukan untuk memperoleh informasi terkait hal-hal yang dihadapi oleh masyarakat Desa Paguyuban, khususnya dalam hal pemasaran produk UMKM. Hasil FGD tim PKM dengan aparat Desa Paguyuban antara lain sebagai berikut:

a. Akibat dari adanya pandemi covid 19, para pelaku UMKM di Desa Paguyuban merasakan dampak yang luar biasa.

b. Daya beli masyarakat terhadap produk-produk UMKM semakin menurun.

c. Pendapatan masyarakat dan pendapatan UMKM semakin menurun.

d. Hal ini dikarenakan pemasaran produk pelaku UMKM masih bersifat konvensional, sehingga pemasaran produk UMKM belum maksimal.

e. Produksi home industry yang ada di Desa Paguyuban kian menurun.

f. Perlu adanya bantuan peningkatan sumber daya manusia atau pemberdayaan masyarakat dalam bentuk pelatihan pemasaran produk melalui pemanfaatan digital marketing.

g. Kepala Desa meminta untuk masing-masing kepala dusun untuk menyiapkan 5 orang perwakilan yang akan menjadi peserta pelatihan Pemanfaatan Digital Marketing Dalam Pemasaran Produk Para Pelaku UMKM di Desa Paguyuban Kecamatan Way Lima Kabupaten
Pesawaran. Peserta pelatihan diminta untuk dapat membawa smartphone/gadget yang telah diisi kuota. Perwakilan tersebut nantinya diharapkan dapat membantu para pelaku UMKM di dusunnya untuk memasarkan produk UMKM melalui media sosial (facebook dan instagram) dan marketplace shopee.

h. Kepala Desa juga akan mengundang Ketua PKK Desa Paguyuban, Pengurus BUMDes Desa Paguyuban, Karang Taruna Desa Paguyuban dan mengajak aparat Desa Paguyuban untuk turut serta dalam pelatihan tersebut.

Kegiatan pengabdian kepada masyarakat berupa pelatihan Pemanfaatan Digital Marketing Dalam Pemasaran Produk Para Pelaku UMKM di Desa Paguyuban Kecamatan Way Lima Kabupaten Pesawaran dilaksanakan pada hari minggu tanggal 1 Agustus 2021 di GSG Desa Paguyuban diikuti oleh 31 orang. Kegiatan pelatihan dibuka secara resmi oleh Kepala Desa Paguyuban Bapak Imam Khudrli (Gambar 3).

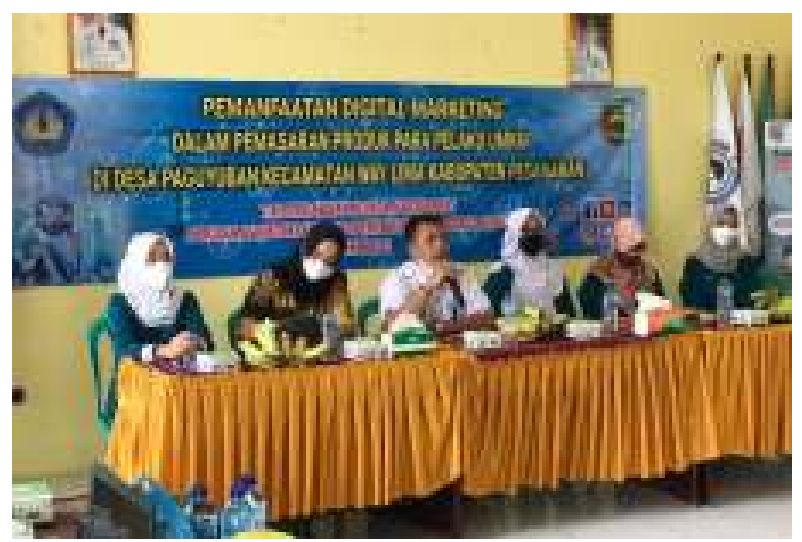

Gambar 3. Pelatihan dibuka secara resmi oleh Kepala Desa Paguyuban

Sebelum kegiatan pelatihan dimulai, peserta diminta untuk mengisi daftar hadir dan mengambil bahan pelatihan di meja penerimaan. Kemudian peserta diminta untuk mengerjakan soal pre-test terkait konsep digital marketing (Gambar 4). 


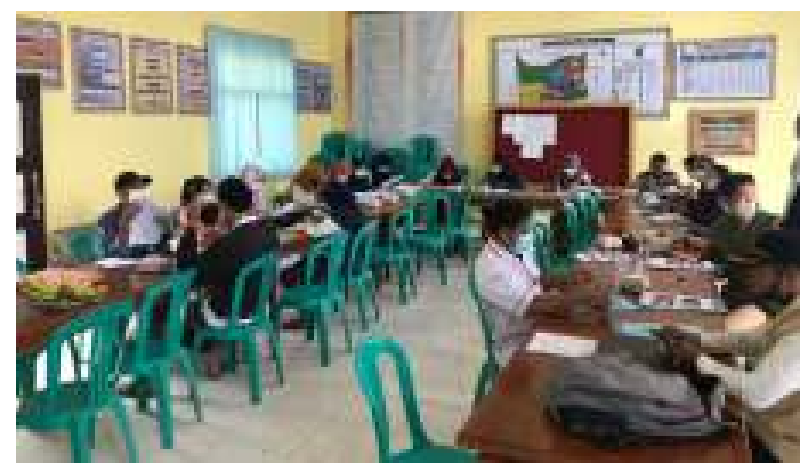

Gambar 4. Peserta mengerjakan soal pre-test

Kemudian ketua tim Pengabdian Kepada Masyarakat Universitas Lampung Ibu Yuliana Saleh, S.P., M.Si. memperkenalkan anggota timnya dihadapan seluruh peserta (Gambar 5). Ketua tim menjelaskan alasan betapa pentingnya pelatihan ini dilaksanakan untuk para pelaku UMKM. Peserta diminta untuk dapat mengikuti pelatihan dengan sungguh-sungguh.

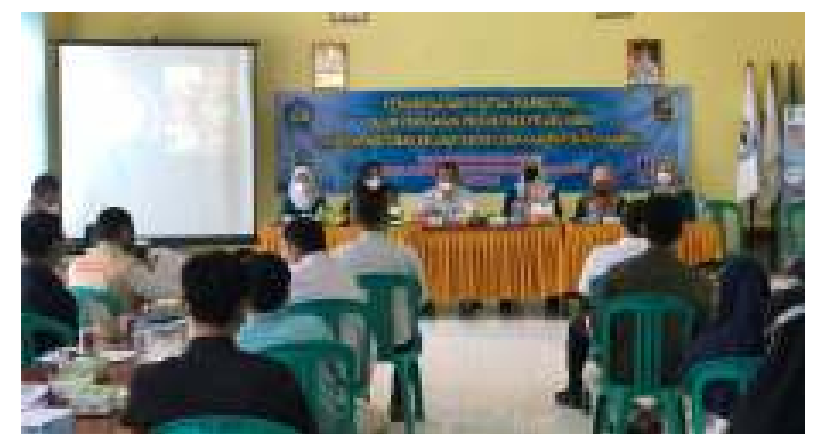

Gambar 5. Pembukaan oleh ketua tim PKM Universitas Lampung

Pelatihan diisi oleh Ibu Dian Rahmalia, S.P., M.Si. terkait konsep digital marketing dan produkproduk teknologi yang dapat digunakan untuk pemasaran produk (Gambar 6). Penggunaan internet yang tinggi di kalangan masyarakat membuat digital marketing ini banyak dipilih. Digital Marketing merupakan kegiatan yang dilakukan untuk memasarkan produk (promosi) dengan media digital yaitu menggunakan teknologi internet. Digital marketing ini memiliki tujuan untuk menarik calon konsumen secara tepat dengan lebih murah dan praktis. Menurut Forka Indonesia (2021), 90\% interaksi kita dengan media kini difasilitasi oleh layar ponsel pintar, layar tablet, layar laptop, dan layar televisi. Dan dibalik interaksi berbasis layar ini, tulang punggungnya adalah internet. Internet sebagai salah satu fondasi kunci dari pemasaran.

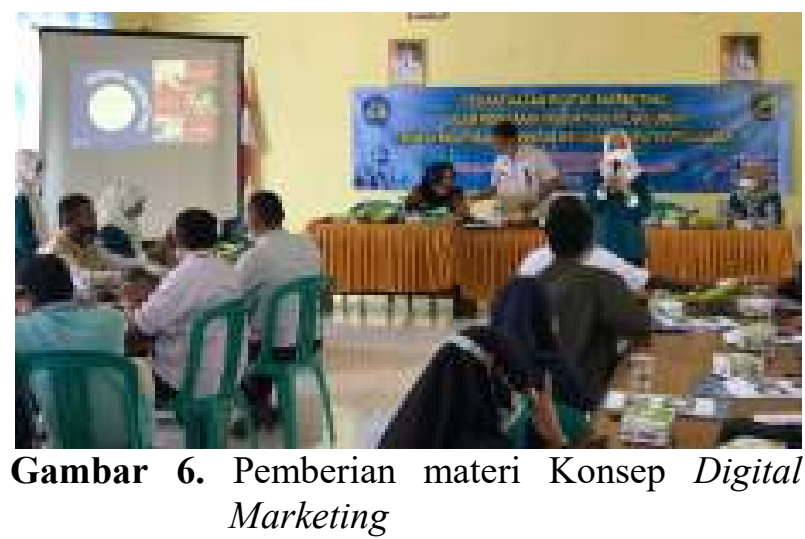

Selanjutnya, para peserta dibagi ke dalam 3 kelompok. Kelompok yang pertama akan melakukan praktik pemasaran produk secara online menggunakan media sosial facebook dan instagram didampingi oleh Ibu Yuliana Saleh, S.P., M.Si. (Gambar 7).

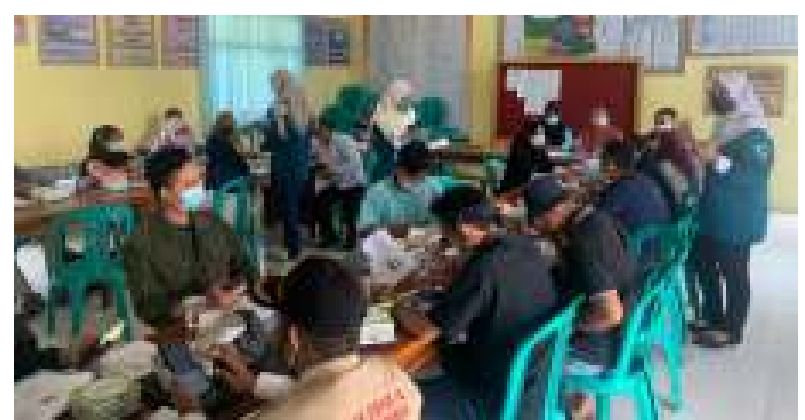

Gambar 7. Praktik pemasaran produk secara online menggunakan media sosial facebook dan instagram

Facebook Marketplace adalah tempat bagi orang untuk menemukan, membeli, dan menjual barang. Dengan mendaftar di Marketplace, kita dapat menjangkau pembeli yang lebih banyak. Facebook Marketplace merupakan fitur facebook yang memungkinkan kita untuk berjualan secara online seperti pada umumnya. Facebook Marketplace sudah ada di aplikasi Facebook. Facebook Marketplace tidak dikenakan biaya pendaftaran. Para peserta dapat mengikuti instruksi yang diberikan, karena sebagai besar peserta sudah memiliki akun Facebook dan para peserta dapat langsung mempromosikan produk UMKM nya di Facebook Marketplace. Selanjutnya, para peserta juga diminta untuk membuat akun bisnis di instagram dan diminta untuk membuat promosi salah satu produk UMKM nya. Setelah semua 
peserta berhasil membuat promosi produk UMKM, sesama peserta melakukan kunjungan promosi produk di akun facebook dan instagramnya serta melakukan kegiatan tanya jawab seputar produk yang akan diperjualbelikan melalui chat atau kolom komentar. Hambatan yang dihadapi oleh para peserta dalam melakukan promosi produk UMKM melalui facebook dan instagram yaitu kurangnya kemampuan peserta dalam membuat pesan persuasif yang menarik, foto produk UMKM yang diupload terlihat kurang menarik calon konsumen, dan sinyal yang kurang stabil di lokasi pelatihan.

Kelompok yang kedua, peserta akan melakukan praktik pemanfaatan marketplace shopee didampingi oleh Ibu I.Rani Mellya Sari, S.P., M.Si. (Gambar 8). Marketplace adalah platform yang berperan sebagai pihak ketiga atau perantara antara penjual dan pembeli untuk mempermudah transaksi jual beli secara online, contohnya Shopee. Shopee merupakan salah satu marketplace asal Singapura, marketplace ini sudah mengekspansi pasar Asia Tenggara sejak tahun 2015 lalu, termasuk ke Indonesia. Setelah empat tahun melakukan ekspansi, akhirnya shopee berhasil menduduki posisi marketplace terbesar ketiga di Indonesia.

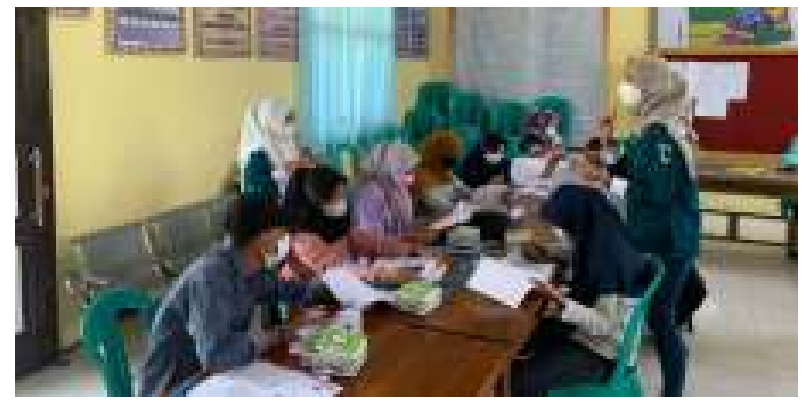

Gambar 8. Praktik pemanfaatan marketplace shopee

Sebagian peserta sudah memiliki akun Shopee, namun penggunaannya hanya sebatas pembelian saja, belum kepada penjualan produk. Selanjutnya para peserta diminta untuk mendownload akun shopee di play store. Para peserta diminta untuk mempromosikan produk UMKM yang akan di jual di Shopee secara langsung. Para peserta mampu mengikuti langkahlangkah yang diberikan oleh instruktur. Hambatan yang dihadapi para peserta adalah kurangnya kemampuan peserta dalam mendeskripsikan produk UMKM nya secara lengkap, peserta juga belum memiliki konsep pembayaran produk yang akan diperjualbelikan secara matang, peserta juga belum memiliki konsep pengiriman produk (JNE, Tiki, dll), dan kurangnya kemampuan peserta dalam merespon calon konsumen yang bertanya terkait produk yang dipromosikan.

Kelompok yang ketiga, peserta akan praktik pembuatan konten promosi yang menarik (content marketing) didampingi oleh Ibu Shinta Tantriadisti, S.P., M.Si. (Gambar 9). Content marketing adalah strategi pemasaran dengan cara menghasilkan konten yang bertujuan untuk memberi informasi kepada target (konsumen) yang bersifat persuasi atas produk yang dipasarkan (Lieb, 2012). Aplikasi yang dapat digunakan untuk membuat content marketing, diantaranya Canva dan Kinemaster. Para peserta diminta untuk membuat content marketing menggunakan gadget/smarphone yang dimiliki peserta dengan bermodalkan gambar produk UMKM yang dimiliki. Para peserta berhasil membuat content marketing, hanya saja content marketing yang dibuat masih sederhana, mungkin karena keterbatasan waktu yang dimiliki.

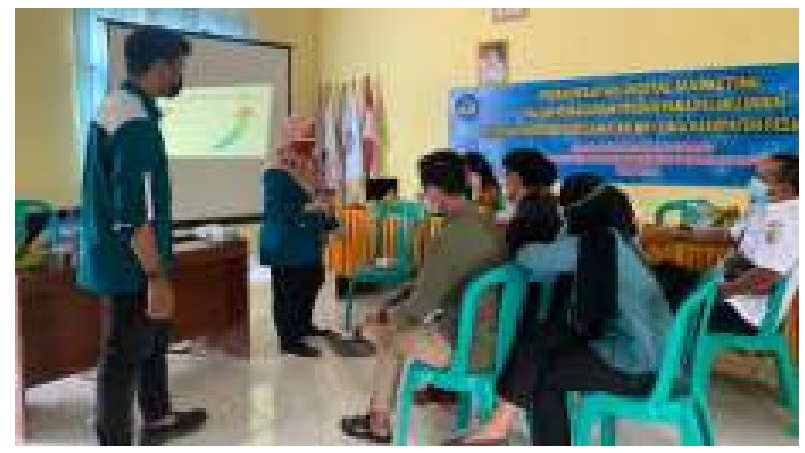

Gambar 9. Praktik pembuatan konten promosi yang menarik

Ketiga kelompok tersebut juga didalamnya melakukan praktik menyusun pesan persuasif efektif, sehingga calon konsumen semakin tertarik untuk membeli produk UMKM. Pesan persuasif yang efektif mencakup empat komponen penting, yaitu menetapkan kredibilitas, membuat kerangka argumentasi, menghubungkan calon konsumen dengan hal-hal yang logis, dan memperkuat posisi dengan penggunaan bahasa yang baik dan tepat bertujuan untuk dapat mempengaruhi calon konsumen, agar mau membeli produk yang kita miliki.

Setelah semua peserta selesai melakukan praktik digital marketing secara langsung, para peserta diminta untuk mengerjakan soal post-test. 
Para peserta tidak memerlukan waktu yang lama untuk mengerjakan soal, karena soal yang diberikan sama dengan soal saat pre-test. Para peserta dengan mudah mengerjakan soal post-test yang diberikan.

Setelah kegiatan pelatihan dilaksanakan, kegiatan pengabdian kepada masyarakat dilanjutkan dengan pendampingan (anjang sana dan anjang karya) kepada sasaran. Kegiatan pendampingan dilakukan oleh ketua dan anggota tim. Pendampingan dilaksanakan selama 2 bulan kegiatan. Kegiatan pelatihan dan pendampingan ini sangat baik dan tepat sasaran. Dari kegiatan ini diharapkan dapat meningkatkan wawasan dan kemampuan para pelaku UMKM dalam memasarkan produknya dengan memanfaatkan digital marketing dalam upaya meningkatkan pendapatan dan kesejahteraan.

Kegiatan pengabdian kepada masyarakat ini telah dapat berjalan dengan lancar dan tertib berkat dukungan dari sasaran, aparat pemerintah desa Paguyuban, pengurus PKK Desa Paguyuban, Pengurus BUM Desa Paguyuban, Karang Taruna Desa Paguyuban, para pelaku UMKM yang ada di Desa Paguyuban sebagai peserta kegiatan pengabdian kepada masyarakat. Keberhasilan kegiatan ini ditunjukkan dengan adanya peningkatan pengetahuan peserta terkait digital marketing, setelah dilakukan kegiatan pelatihan dan pendampingan.

Evaluasi pengetahuan peserta pelatihan terkait materi-materi "Pemanfaatan Digital Marketing Dalam Pemasaran Produk Para Pelaku UMKM di Desa Paguyuban Kecamatan Way Lima Kabupaten Pesawaran" dilakukan dengan membandingkan hasil kuesioner awal (pre-test) dan kuesioner akhir (post-test). Dari 10 soal yang telah disediakan, secara umum pengetahuan peserta pelatihan mengalami peningkatan setelah diadakannya kegiatan pengabdian kepada masyarakat. Peningkatan pengetahuan peserta ini dapat dilihat dari jawaban peserta setelah mengerjakan soal pre-test dan post-test. Peningkatan pengetahuan peserta ini dapat dilihat dari jawaban orang yang menjawab soal dengan benar dapat dilihat pada Gambar 10 .

Sebelum dilaksanakannya kegiatan pengabdian kepada masyarakat, peserta banyak yang belum sadar akan pentingnya pemanfaatan digital marketing dalam memasarkan produk para pelaku UMKM di Desa Paguyuban Kecamatan Way Lima Kabupaten Pesawaran.

\section{Perbandingan Pre-Test dan Post- Test Berdasarkan Butir Soal}

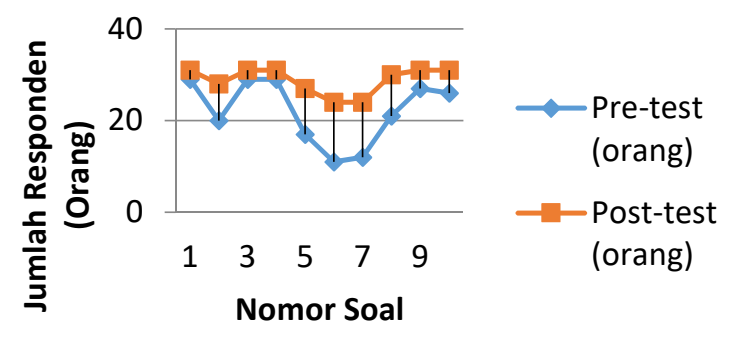

Gambar 10. Peningkatan pengetahuan peserta yang menjawab soal dengan benar

Setelah dilaksanakannya kegiatan pengabdian kepada masyarakat dalam bentuk pelatihan, secara umum didapatkan hasil bahwa pelatihan ini dapat meningkatkan pengetahuan peserta. Hal ini ditunjukkan oleh nilai pre-test rata-rata yang diperoleh peserta yaitu 7 menjadi 9 untuk nilai posttest yang diperolehnya atau meningkat sebesar $23,26 \%$. Perbandingan nilai pre-test dan post-test peserta pelatihan dapat dilihat pada Gambar 11.

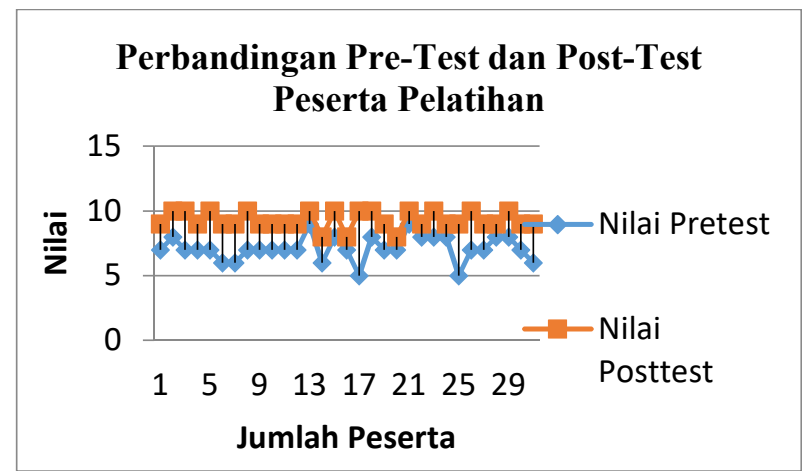

Gambar 11. Perbandingan nilai pre-test dan posttest peserta pelatihan

Pelaksanaan pelatihan dan pendampingan berjalan dengan baik. Para peserta memberikan respon yang aktif dalam simulasi produknya secara online dan menanyakan hal-hal yang belum dapat dipahami bersama dan mencari solusi yang terbaik. Diskusipun berlangsung aktif, bahkan para peserta saling memberikan pendapat berdasarkan pengalaman yang telah mereka lakukan.

Keberhasilan kegiatan pengabdian kepada masyarakat ini dapat berjalan dengan baik, karena didukung oleh beberapa hal yaitu a) materi yang diberikan sesuai dengan permasalahan yang dihadapi masyarakat saat ini, b) masyarakat desa 
sudah dapat membaca dan menulis, sehingga memudahkan masyarakat untuk mengerjakan soal pre-test dan post-test yang diberikan, c) masyarakat desa dengan mudah dapat menyerap informasi yang diberikan, d) metode pelatihan yang dilakukan sesuai dengan kondisi yang ada, e) besarnya minat sasaran untuk meningkatkan pengetahuan terkait pemanfaatan digital marketing dalam memasarkan produk para pelaku UMKM di Desa Paguyuban, dan f) dukungan sasaran (Aparat Desa Paguyuban, BUMDes, Karang Taruna, PKK, para pelaku UMKM).

Kegiatan pendampingan juga dilakukan oleh ketua dan anggota tim setelah adanya kegiatan pelatihan. Pendampingan dilaksanakan selama 2 bulan kegiatan. Sebelum adanya pendampingan, para pelaku UMKM di Desa Paguyuban melakukan pemasaran produk secara konvensional dan belum menerapkan pemasaran produk secara online (digital marketing). Para pelaku UMKM hanya memasarkan produknya ke pasar-pasar terdekat atau di warung-warung sekitar.

Namun, setelah adanya pendampingan, para pelaku UMKM mulai memasarkan produknya dengan memanfaatkan digital marketing seperti facebook marketplace, instagram, dan shopee. Hal ini menunjukkan bahwa kegiatan pelatihan dan pendampingan ini sangat baik dan tepat sasaran.

\section{Kesimpulan}

Kegiatan pengabdian kepada masyarakat berjalan dengan baik dan dapat meningkatkan pengetahuan masyarakat dari nilai rata-rata 7 menjadi 9 atau meningkat 23,26\%. Kegiatan pelatihan dan pendampingan ini sangat baik dan tepat sasaran. Dari kegiatan ini, masyarakat mulai a) memahami konsep digital marketing dan produkproduk teknologi yang dapat digunakan untuk pemasaran produk UMKM, b) melakukan praktik/simulasi pemasaran produk UMKM dengan menggunakan media digital seperti facebook marketplace, instagram, dan shopee, c) menyusun pesan persuasif efektif dan menarik, sehingga calon pembeli semakin tertarik untuk membeli produk UMKM nya, dan d) membuat akun media sosial yang dikelola oleh para pelaku UMKM yang digunakan untuk mensosialiasikan dan mempromosikan produk UMKM nya.

\section{Ucapan Terima Kasih}

Tim dosen pengabdian kepada Masyarakat, mengucapkan terima kasih kepada Universitas Lampung yang telah membiayai kegiatan ini melalui program Pengabdian Kepada Masyarakat Dosen Pemula Universitas Lampung, sehingga kegiatan dapat berjalan dengan lancar dan memberikan dampak positif bagi masyarakat Desa Paguyuban.

\section{Daftar Pustaka}

Febriyantoro, M. T. \& Arisandi, D. (2018). Pemanfaatan Digital Marketing Bagi Usaha Mikro, Kecil Dan Menengah Pada Era Masyarakat Ekonomi Asean. JMD: Jurnal Riset Manajemen \& Bisnis Dewantara, 1(2), 61-76.

Forka Indonesia. (2021). Community-Based Media Movement During Pandemic Breakout. https://forka.id/media-movement.html.

Guna, M., Daya, M., Dalam, S., \& Asean, M.E. (2013). Optimalisasi Pemanfaatan Teknologi Informasi Komunikasi Berbasis E-Commerce Sebagai Media Pemasaran Usaha Kecil Menengah Guna Meningkatkan Daya Saing Dalam Menghadapi Masyarakat Ekonomi Asean 2015. Economics Development Analysis Journal, 2(2), 135-139.

Hendriadi, Ade Andri., Sari, Betha Nurina., \& Padilah, Tesa Nur. (2019). Pelatihan Digital Marketing Usaha Mikro, Kecil dan Menengah (UMKM) di Kabupaten Karawang. Jurnal Pengabdian Masyarakat J-DINAMIKA, 4(2), 120-124.

Lieb, Rebecca. (2012). Content Marketing: Think Like a Publisher- how to Use Content to Market Online and in Social Media. Amerika Serikat : Que Publishing.

Pradiani, T. (2018). Pengaruh Sistem Pemasaran Digital Marketing Terhadap Peningkatan Volume Penjualan Hasil Industri Rumahan. Jurnal Ilmiah Bisnis dan Ekonomi Asia, 11(2), 46-53.

Purwana, D., Rahmi, R., dan Aditya, S. (2017). Pemanfaatan Digital Marketing Bagi Usaha Mikro, Kecil, dan Menengah (UMKM) di Kelurahan Malaka Sari, Duren Sawit. Jurnal Pemberdayaan Masyarakat Madani (JPMM), 1(1), 1-17. 